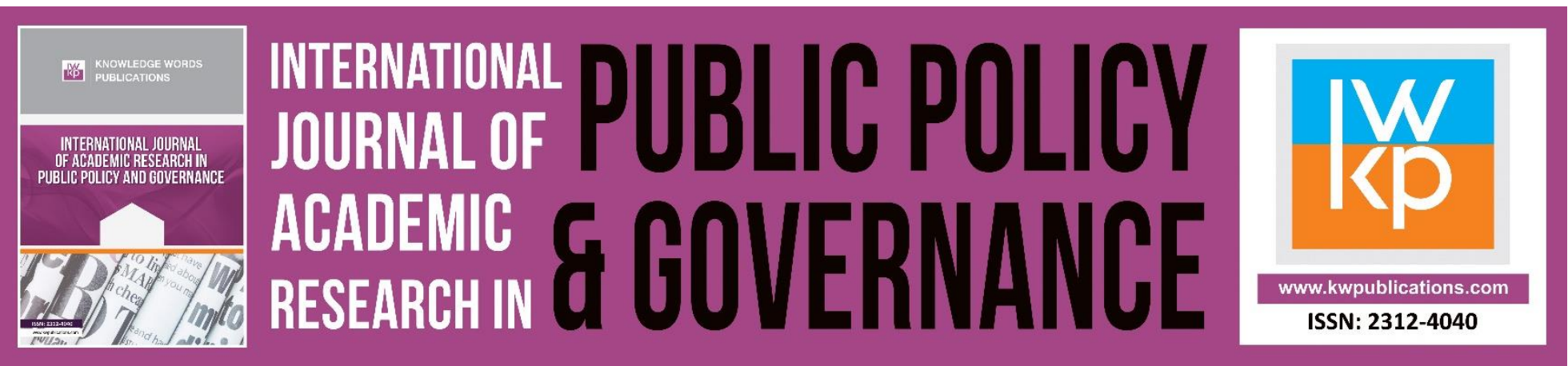

\title{
Challenges Encountered by Learners with Visual Impairment in Integrated Classroom in Bungoma County Kenya
}

Mihegwa, H., Mutsotso, S. N., \& Masibo, E.

To Link this Article: http://dx.doi.org/10.46886/IJARPPG/v7-i1/7125

DOI:10.46886/IJARPPG/v7-i1/7125

Received: 06 January 2020, Revised: 14 February 2020, Accepted: 19 February 2020

Published Online: 21 March 2020

In-Text Citation: (Mihegwa et al., 2020)

To Cite this Article: Mihegwa, H., Mutsotso, S. N., \& Masibo, E. (2020). Challenges encountered by learners with Visual Impairment in Integrated Classroom in Bungoma County Kenya. International Journal of Academic Research in Public Policy and Governace, 7(1), 39-49.

\section{Copyright: (c) 2020 The Author(s)}

Published by Knowledge Words Publications (www.kwpublications.com)

This article is published under the Creative Commons Attribution (CC BY 4.0) license. Anyone may reproduce, distribute, translate and create derivative works of this article (for both commercial and non-commercial purposes), subject to full attribution to the original publication and authors. The full terms of this license may be seen at: http://creativecommons.org/licences/by/4.0/legalcode

Vol. 7, No.1, 2020, Pg. $39-49$ 


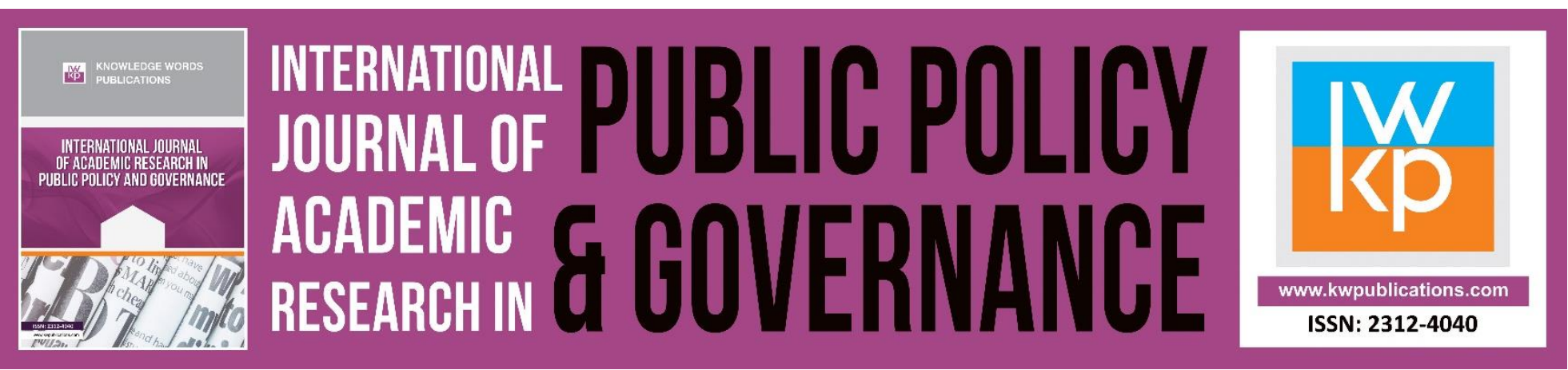

\title{
Challenges Encountered by Learners with Visual Impairment in Integrated Classroom in Bungoma County Kenya
}

\author{
Mihegwa, H., Mutsotso, SN., Masibo, E. \\ Schoolof Graduate Studies in Arts in History Kibabii University \\ Email: helenmihegwa@yahoo.com,smutsotso@kibu.ac.ke,emasibo@kibu.ac.ke
}

\begin{abstract}
Learning is a continuous process of acquiring skills, knowledge and attitudes within any environment that learning takes place and begins at early age when a child starts to explore the surroundings around him/her. However, this may not be uniform for all children because of numerous challenges that some of them encounter. This study was to determine how teachers mediated for learner classroom performance among the Visually Impaired learners in integrated secondary schools in Bungoma, Kenya. Variables in the objectives were, different categories of visual impairment, teacher characteristics, influence of instructional resources, challenges encountered and how the challenges were mediated for. The study was in line with the argument of Dewey which has been supported by Gutek, Schiro, Taylor, Flinders and Thornton in the $21^{\text {st }}$ Century. Dewey was the proponent of progressive education which emphasized the need to learn by doing. He stressed that, there was a need to see education as a single process involving teaching and learning. The study was carried out in integrated secondary schools in Bungoma County, Kenya. Descriptive survey research design was adopted by the study. The population that was targeted was derived from integrated secondary schools. The schools were stratified in categories of boys' school and girls' school. The respondents for the study were sampled using Simple random sampling. The collection of data was done using teachers, learners, teacher aide and caretakers questionnaire. Interviews were scheduled for teachers, visually impaired learners and learners with sight. Descriptive statistics was used to analyze quantitative data presenting data in summary frequencies and percentage. Tables and charts were also used to present data. The study findings were presented as per the objectives of the study and could be used by educational policy makers and stakeholders to plan on how to provide education that was quality for learners who had difficulties with sight and enhance their active participation in class, school and community activities in Bungoma County. It was concluded that, learners with visual impairment were categorized as blind, low vision and visual disorder. Teachers found it difficult though they tried to interpret the curriculum to suit all learners. They found difficulties in following a lesson plan prepared for learners with visual impairment, and providing differentiated tasks. There were inadequate learning resources and those available did not benefit all learners and were not readily available during class instructions. Learners with visual impairment encountered more challenges in integrated classrooms which were overcrowded and the
\end{abstract}


environment not modified. The school community had misconception about learners with visual impairment. The study therefore recommended that, all learners be given equal opportunity to learn, teachers to be given training in Special Needs Education, learning environment be modified and schools to source for funds to buy instructional resources. Serving Special Needs Teachers with qualifications of a degree and above be deployed in integrated secondary schools to support with the transition from primary schools to secondary schools. Parents to support their children with visual impairment while in school. The study could as well help to establish the classroom dynamics in mediating learner performance among the visually impaired learners in integrated secondary schools in Bungoma County, Kenya.

Keywords: Classroom Dynamics, Learner Challenges, Visual Impairment, Integrated Classrooms.

\section{Introduction}

Blindness could occur in combination of other disabilities like intellectual disabilities, autism spectrum disorders, cerebral palsy, hearing impairment and epilepsy. This posed a challenge to the learner with Visual Impairment (V.I) placed in an integrated classroom. These learners become isolated from others more easily making it difficult for them to participate actively like the sighted learners. Solomon M. W(2009) stated that, the teaching methods some teachers used did not carter for the learner with V.I in integrated classrooms. The classes were over enrolled leaving the learner with Visual Impairment with little opportunity to compete against those learners with sight. The learner with Visual Impairment(V.I) found challenges in integrated classes when there was lack of program modifications and support for class personnel needed for a learner to ensure that the learner's unique needs arising from Visual Impairment were appropriately addressed in the Individualized Education Program (I.E.P). There was also lack of appropriate assistive technology and the full range of assistive technology devices and services as well as lack of instructions prepared in electronic format to make it easier to provide materials and allow the learner with Visual Impairment (V.I) to adapt the information to a format which was suitable for them. Learners living with Visual Impairment admitted in integrated classes faced consistent stigma and stereotype as perceived by teachers and other learners as having inferior intellectual abilities and knowledge. They become fatigued more quickly and had difficulty focusing on a given task. Learners with Visual Impairment lacked the ability to independently move around the classroom rendering them a burden to other members of the class hence developing low self- esteem which subsequently affected their academic performance. They lacked orientation and mobility services due to lack of qualified personnel to enable them to attain systematic orientation and safe movement within their classroom environment. Learners with Visual Impairment (V.I) had a shortage of educational support materials and equipment.

Other challenges faced by learners with visual impairment in integrated classes included, lack of supplementary aids, services and devices to facilitate their involvement in the general classroom instructions. They lacked instructions in Braille which was a very effective medium in reading and writing for many learners living with visual impairment. Although the learners living with Visual Impairment were being cared for in their primary, tertiary and university education as indicated in education policies, there existed a gap in their secondary education that had to be addressed to enhance their performance. 
INTERNATIONAL JOURNAL OF ACADEMIC RESEARCH IN PUBLIC POLICY AND GOVERNANCE

Vol. 7, No. 1, 2020, E-ISSN:2312-4040@ 2020 KWP

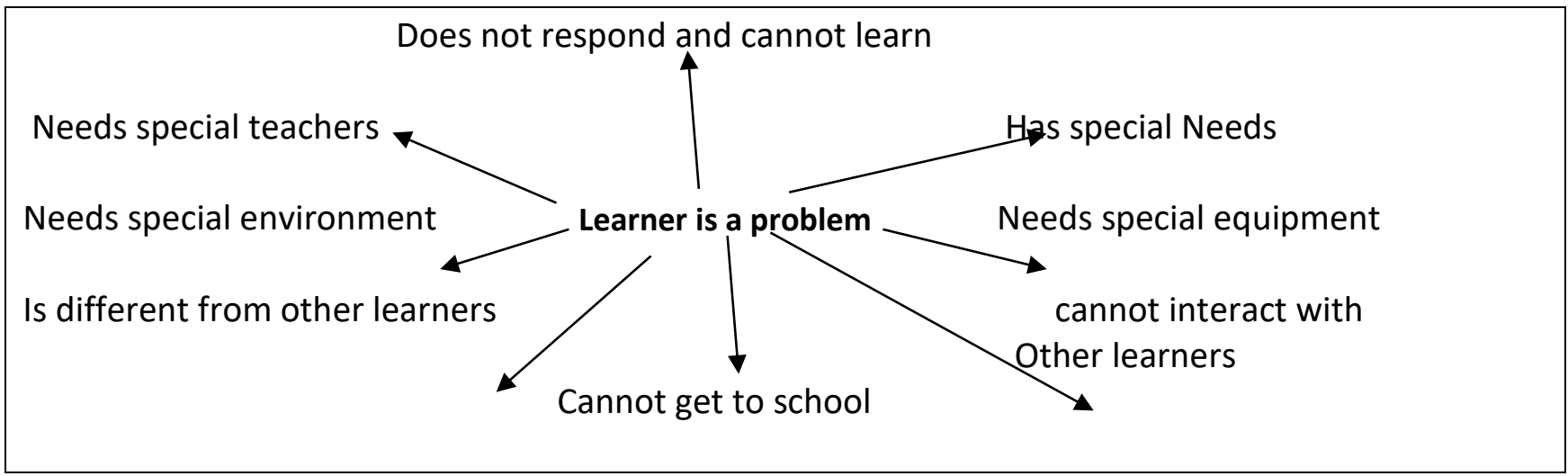

Figure 1: How a learner with Visual Impairment is viewed in integrated programme

Adapted from: Introduction to inclusive education, KISE/UNISE (2009)

Basing on the diagram above, the big question remains, how do you go about changing the attitude of people so that the learner is not viewed as a problem.

\section{Methodology}

The study adopted the descriptive research design which allows the researcher to select a sample of respondents from a population. The area of study was in public integrated secondary schools in Bungoma County Kenya. The study focused on Bungoma boys high school and Misikhu girls high school so as to have gender equity. These are currently the only integrated secondary schools in Bungoma County. The study targeted teachers, teacher aide, caretakers, learners with and without Visual Impairment as shown below.

Table 1: Target population

\begin{tabular}{lccc}
\hline Attribute & Category & Frequency & Percentage \\
\hline Teachers & Males & 40 & 13.93 \\
& Female & 60 & 20.90 \\
Teacher Aide & Males & 1 & 0.34 \\
\multirow{2}{*}{ Caretakers } & Female & 1 & 0.34 \\
& Male & 2 & 0.69 \\
Learners with V.I & Female & 3 & 1.04 \\
& Male & 20 & 6.96 \\
Learners without V.I & Female & 10 & 3.48 \\
& Male & 70 & 24.39 \\
& Female & 80 & 27.87 \\
\hline
\end{tabular}

The table shows that, 100 (35\%) teachers, 2 (0.7\%) teacher aide, 5 (1.7\%) caretakers, $30(11 \%)$ learners with Visual Impairment and 150 (52\%) learners without Visual Impairment comprised the target population. All the respondents were found within the sampled integrated schools. The respondents comprised both male and female. Random Sampling was used to give every item in the population an equal opportunity through indexing of the items of target population to be able to select sample size for respondents. Stratified sampling was used to select boys and girls. Simple Random Sampling was used to sample teachers and learners without Visual Impairment. Purposive Sampling was used to sample learners with Visual Impairment, caretakers and teacher aide. The 
INTERNATIONAL JOURNAL OF ACADEMIC RESEARCH IN PUBLIC POLICY AND GOVERNANCE Vol. 7, No. 1, 2020, E-ISSN:2312-4040@ 2020 KWP

percentages used were within the range of $10 \%$ and $30 \%$ as proposed by Mugenda and Mugenda(2003) as indicated below.

Table 2: Sampling Criteria of different Categories of respondents

\begin{tabular}{|c|c|c|c|c|}
\hline $\begin{array}{l}\text { Categories of } \\
\text { respondents }\end{array}$ & $\begin{array}{l}\text { Population } \\
\text { (N) }\end{array}$ & $\begin{array}{l}\text { Sample } \\
\text { Population } \\
\text { (n) }\end{array}$ & $\begin{array}{l}\text { Percentage } \\
\text { (\%) }\end{array}$ & $\begin{array}{l}\text { Technique } \\
\text { (Type of sampling) }\end{array}$ \\
\hline Teachers & 100 & 15 & $15 \%$ & Simple random \\
\hline Teacher Aide & 2 & 2 & $100 \%$ & Purposive \\
\hline Caretakers & 5 & 5 & $100 \%$ & Purposive \\
\hline $\begin{array}{l}\text { Learners with Visual } \\
\text { Impairment }\end{array}$ & 30 & 30 & $100 \%$ & Purposive \\
\hline $\begin{array}{l}\text { Learners without } \\
\text { Visual Impairment }\end{array}$ & 150 & 20 & $13.33 \%$ & Simple Random \\
\hline Total & 287 & 72 & & \\
\hline
\end{tabular}

The respondents were sampled to represent the target population. Total population for teachers was 100 teachers and $15(15 \%)$ were sampled for the study. The teachers comprised both regular and those trained in Special Needs Education. The researcher focused on the 15 teachers who were frequently involved in matters that concerned learners who had visual impairment and integrated in the school. The type of sampling technique employed was Simple Random Sampling. Total population for teacher aide was 2 and 2(100\%) were sampled for the study, the form of sampling technique employed was purposive sampling. Total population for caretakers was 5 caretakers and $5(100 \%)$ were sampled for the study, the type of sampling technique employed was purposive sampling. Total population for learners with Visual Impairment was 30 and 30(100\%) were sampled, the type of sampling technique employed was purposive sampling. Total population for learners without Visual Impairment was 150 learners and 20(13.3\%) were sampled for the study, the sampling technique was random sampling. The area of focus for the researcher was mainly on those with visual impairment and that is the reason why 20 out of 150 learners without visual impairment was sampled for the study.

Instruments of Data collection were questionnaire, interview schedules and observation schedule. Questionnaires were used to the sampled teachers, teacher aide and caretakers. Interviews were conducted for learners with and without Visual Impairment. Observation was conducted for teachers while teaching in their classrooms. Content Validity was used to measure the content that was supposed to be measured. Construct Validity measured information that was in line with the set theoretical constructs for the study. Face Validity depended on how the researcher looked at the instrument from the face value through discussion with supervisors. Validity was the degree to which the research instruments measured what was intended to measure, Kothari (2009). The same 
INTERNATIONAL JOURNAL OF ACADEMIC RESEARCH IN PUBLIC POLICY AND GOVERNANCE Vol. 7, No. 1, 2020, E-ISSN:2312-4040@ 2020 KWP

instrument was administered to the same respondents repeatedly over a period of time at different intervals to certain its reliability. Permission was sought from the relevant authorities to conduct the study. The authorities included; Kibabii University, National Commission for Science Technology and Innovation, County Commissioner Bungoma, County Director of Education, TSC Sub County Directors Bungoma South and Bungoma East, lastly the principles from the respective schools.

\section{Results and Discussion}

The study was set up to assess the challenges encountered by learners with Visual Impairment in integrated classrooms in Bungoma County. The results are as presented in the table below:-

Table 3: Teachers Responses to Challenges Encountered in Integrated Classrooms forVisual Impairment

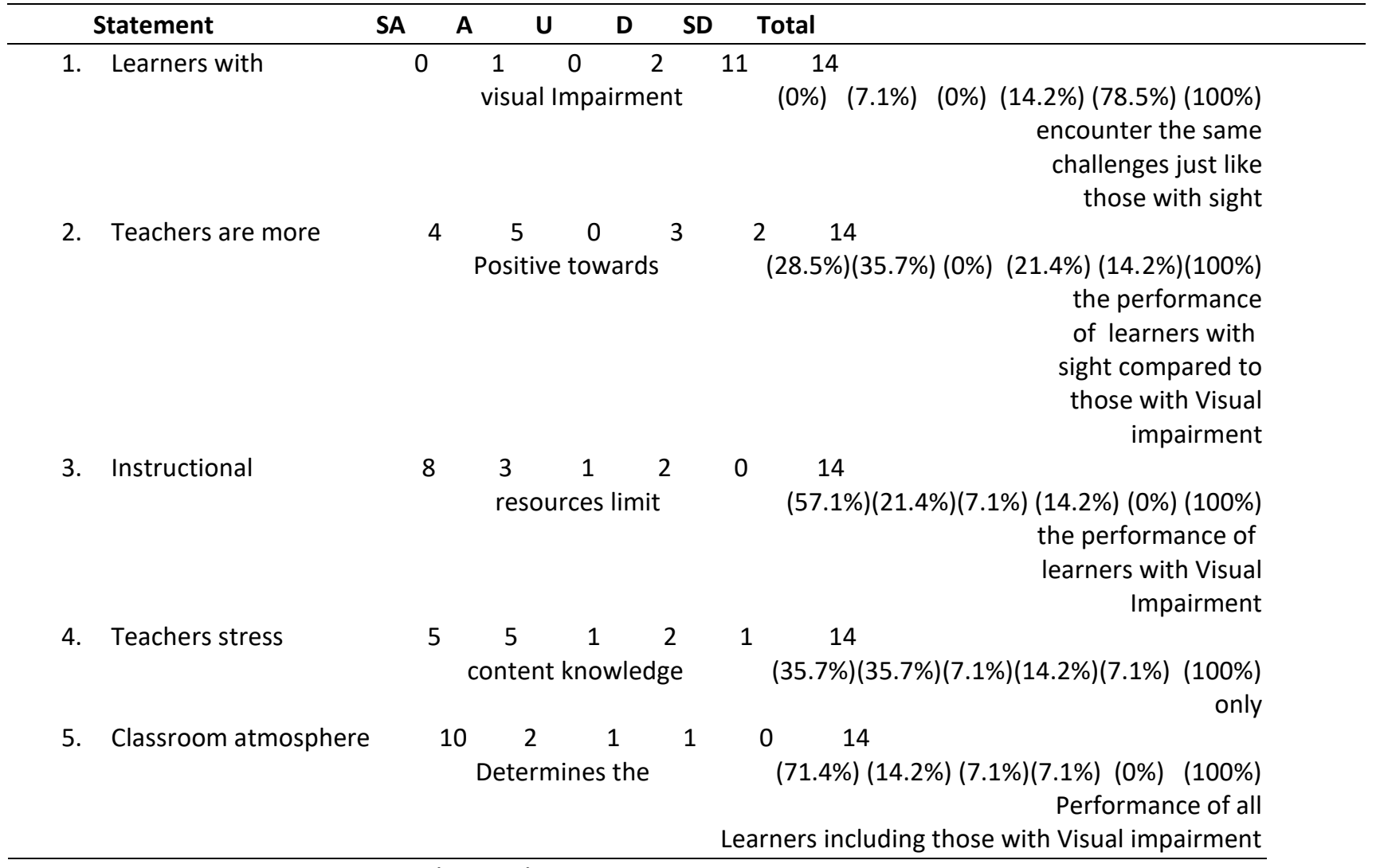

Results in table 3 shows, 11(78.5\%) strongly disagreed that learners with Visual Impairment encounter the same challenges just like those with sight. $2(14.2 \%)$ disagreed but $1(7.1 \%)$ was in agreement. This shows that, the challenges that learners with Visual Impairment go through cannot be compared to those challenges learners with sight go through. Learners with Visual Impairment undergo multiple challenges because of their inability to see.4(28.5\%) strongly agreed that teachers are more positive towards the performance of learners with sight compared to those with Visual Impairment. 5(35.7\%) agreed, 3(21.4\%) disagreed and 2(14.2\%) strongly disagreed. It is evident that teachers are more positive towards learners with sight compared to those with Visual Impairment.8(57.1\%) strongly agreed that instructional resources limit the performance of learners with Visual Impairment. 3(21.4\%) agreed, 1(7.1\%) was undecided and 2(14.2\%) disagreed. In adequate resources compromises the administration of the instructions by the teacher to the learners with Visual Impairment, hence limiting the academic performance of these learners. 
INTERNATIONAL JOURNAL OF ACADEMIC RESEARCH IN PUBLIC POLICY AND GOVERNANCE Vol. 7, No. 1, 2020, E-ISSN:2312-4040@ 2020 KWP

$5(35.7 \%)$ of the respondents strongly agreed that teachers stress content knowledge only. 5(35.7\%) agreed, $1(7.1 \%)$ was undecided, $2(14.2 \%)$ disagreed, $1(7.1 \%)$ strongly disagreed. According to teachers' responses, it is true that majority of teachers stress content knowledge only shying off from hands on activities. This deprives the learner the ability to put into practice the knowledge acquired limiting his/her academic performance. 10(71.4\%) of respondents strongly agreed that classroom atmosphere determines the performance of all learners including those with Visual Impairment. $2(14.2 \%)$ agreed, $1(7.1 \%)$ were undecided and $1(7.1 \%)$ disagreed.

For all learners to perform well regardless of their disability, classroom atmosphere must be conducive. The teachers also mentioned more challenges that affected learners with Visual Impairment in integrated secondary schools which included; Overcrowded classrooms, School community misconception and stigma, inadequate funding for their programs, unfriendly school environment, Insufficient instructional materials like Braille machines and Braille textbooks. The International Journal of Education Research (2016) attributed the poor performance of these learners with Visual Impairment to the teaching resources and methods used by some teachers which did not carter for them. Negative attitude, curriculum that was not adapted, inadequate specialists like eye specialists, lack of individualized educational program and in ability to be included in school activities were some of the challenges learners with Visual Impairment encountered in integrated classrooms. Through interview schedules, teachers agreed that learners with Visual Impairment did not encounter the same challenges like those with sight. They said that learners with Visual Impairment integrated classrooms encountered more challenges than those without Visual Impairment. The teachers' response was supported by the American Academy of Pediatrics and Ophthalmology (2009) which explained that, vision problems could interfere with learning.

Table 4: Teacher Aide and Caretakers Responses on Challenges Encountered in Integrated Classrooms for Visual Impairment

\begin{tabular}{|c|c|c|c|c|c|c|}
\hline Statement & SA & $A$ & $\mathrm{~J}$ & SD & To & otal \\
\hline $\begin{array}{l}\text { 1. Learners with visual } \\
\text { impairment encounter } \\
\text { the same challenges just } \\
\text { like those with sight }\end{array}$ & $\begin{array}{l}0 \\
(0 \%)\end{array}$ & $\begin{array}{c}1 \\
(14.2 \%)\end{array}$ & $\begin{array}{l}0 \\
(0 \%)\end{array}$ & $\begin{array}{l}2 \\
(28.5 \%)\end{array}$ & $\begin{array}{l}4 \\
(57.1 \%)\end{array}$ & $\begin{array}{l}7 \\
(100 \%)\end{array}$ \\
\hline $\begin{array}{l}\text { 2. Teachers are more positive } \\
\text { towards the performance of } \\
\text { learners with sight compared } \\
\text { to those with visual impairme }\end{array}$ & $\begin{array}{l}2 \\
\quad(28.5 \% \\
\text { ent }\end{array}$ & $\begin{array}{l}4 \\
\%)(57.1 \%)\end{array}$ & $\begin{array}{l}0 \\
(0 \%)\end{array}$ & $\begin{array}{l}1 \\
(14.2 \%)\end{array}$ & $\begin{array}{l}1 \\
(14.2 \%\end{array}$ & $\begin{array}{l}7 \\
\text { 6) }(100 \%)\end{array}$ \\
\hline $\begin{array}{l}\text { 3. Instructional resources limit } \\
\text { the performance of learners } \\
\text { with visual impairment }\end{array}$ & $\begin{array}{l}5 \\
(71.4 \%\end{array}$ & $\begin{array}{c}1 \\
\text { o) }(14.2 \%)\end{array}$ & $\begin{array}{l}0 \\
(0 \%)\end{array}$ & $\begin{array}{c}1 \\
(14.2 \%)\end{array}$ & $\begin{array}{l}0 \\
(0 \%)\end{array}$ & $\begin{array}{c}7 \\
(100 \%)\end{array}$ \\
\hline $\begin{array}{l}\text { 4. Teachers stress content } \\
\text { knowledge only }\end{array}$ & $\begin{array}{c}4 \\
57.1 \%)\end{array}$ & $\begin{array}{c}3 \\
(42.8 \%) \quad(C\end{array}$ & $\begin{array}{c}0 \\
(0 \%)\end{array}$ & $\begin{array}{c}0 \\
(0 \%)\end{array}$ & $\begin{array}{c}0 \\
(0 \%) \quad(1\end{array}$ & $\begin{array}{c}7 \\
100 \%)\end{array}$ \\
\hline $\begin{array}{l}\text { 5. Classroom atmosphere } \\
\text { determines the performance } \\
\text { of all learners including those }\end{array}$ & $\begin{array}{l}3 \\
(42.8 \% \\
\text { with vis }\end{array}$ & $\begin{array}{l}3 \\
(42.8 \%) \\
\text { ual impairı }\end{array}$ & $\begin{array}{l}0 \\
\quad(0 \%) \\
\text { rment }\end{array}$ & $\begin{array}{l}1 \\
(14.2 \%)\end{array}$ & $\begin{array}{l}0 \\
(0 \%)\end{array}$ & $\begin{array}{l}7 \\
(100 \%)\end{array}$ \\
\hline
\end{tabular}

Findings in table 4 shows that, 1(14.2\%) of the teacher aide and caretakers agreed that learners with visual impairment encountered the same challenges just like those with sight. 2(28.5\%) disagreed and $4(57.1 \%)$ disagreed. $2(28.5 \%)$ strongly agreed that teachers were more positive 
INTERNATIONAL JOURNAL OF ACADEMIC RESEARCH IN PUBLIC POLICY AND GOVERNANCE Vol. 7, No. 1, 2020, E-ISSN:2312-4040@ 2020 KWP

towards the performance of learners with sight compared to those with visual impaired. 4(57.1\%) agreed and $1(14.2 \%)$ disagreed. $5(71.4 \%)$ of the respondents agreed that instructional resources limit the performance of learners with visual impairment. 1(14.2\%) agreed and 1(14.2\%) disagreed. $4(57.1 \%)$ of the teacher aide and caretakers strongly agreed that teachers stress content knowledge only. 3(42.8\%) agreed. 3(42.8\%) strongly agreed that classroom atmosphere determines the performance of all learners including those with visual impairment, 3(42.8\%) agreed and 1(14.2\%) disagreed.

The teacher aide and caretakers stated that learners with Visual Impairment did not encounter the same challenges like those with sight. They cited teachers being more positive towards the performance of learners with sight compared to those with Visual Impairment. They also explained that the instructional resources limited the performance of learners with visual impairment and teachers stressed content knowledge only. They agreed that the classroom atmosphere determined the performance of all learners including those with Visual Impairment. Jordan \& Kathy- Ann (2014) explained that, appropriate modification of the classrooms was a requirement to meet the varied needs of learners.

Table 5: Responses from Learners on Challenges Encountered in Integrated Classrooms for Visual Impairment

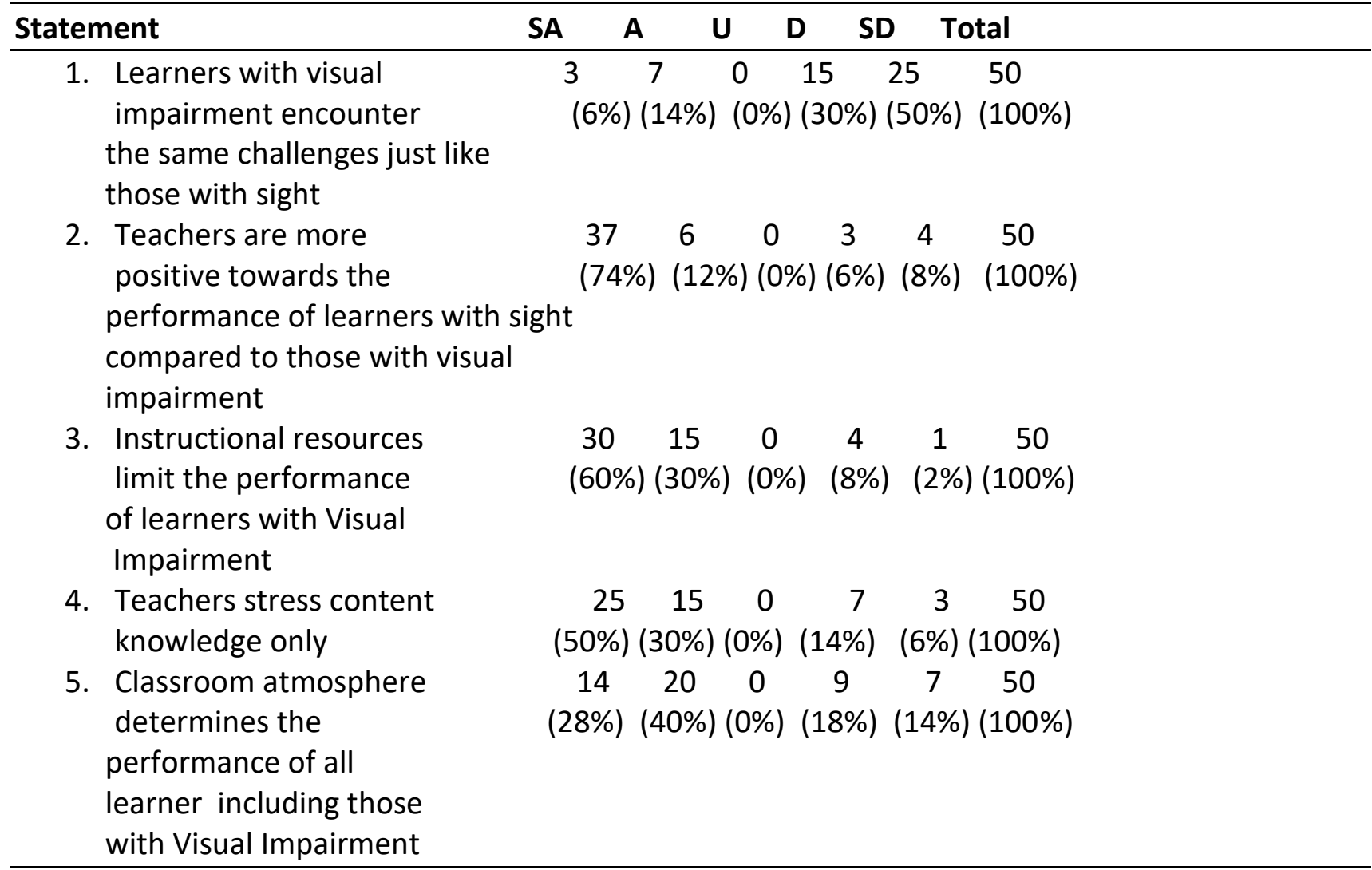

Learners' responses in table 5 shows that, 3(6\%) of the learners strongly agreed that learners with visual impairment encounter the same challenges just like those with sight. 7(14\%) agreed, 15(30\%) disagreed and 25(50\%) strongly disagreed. 37(74\%) strongly agreed that teachers were more positive towards the performance of learners with sight compared to those with visual impairment. 6(12\%) agreed, 3(6\%) disagreed and 4(8\%) strongly disagreed. 30(60\%) strongly agreed that the instructional resources limited the performance of learners with visual impairment. $15(30 \%)$ agreed, $4(8 \%)$ 
INTERNATIONAL JOURNAL OF ACADEMIC RESEARCH IN PUBLIC POLICY AND GOVERNANCE Vol. 7, No. 1, 2020, E-ISSN:2312-4040@ 2020 KWP

disagreed and $1(2 \%)$ strongly disagreed. $25(50 \%)$ strongly agreed that teachers stressed content knowledge only. 15(30\%) agreed, 7(14\%) disagreed, 3(6\%) strongly disagreed. $14(28 \%)$ strongly agreed that classroom atmosphere determines the performance of all learners including those with visual impairment.20(40\%) agreed, 9(18\%) disagreed and 7(14\%) strongly disagreed.

The explanation given by learners was that, learners with Visual Impairment did not encounter the same challenges as those with sight. They claimed that teachers were more positive towards the performance of learners with sight compared to those with Visual Impairment and that instructional resources limited the performance of learners with Visual Impairment. Adunola (2016) explains that, teachers needed to be knowledgeable with various teaching resources which were relevant to the concept to be taught. The learners also stated that, teachers stressed content knowledge only rather than giving learners 'hands on activities to enhance critical thinking. According to Ayieni (2011), the quality of passing knowledge to learners was reflected in the achievements of learners.

Table 6: Summary responses from teachers, teacher aide, caretakers and learners on challenges encountered in integrated classrooms for Visual Impairment in integrated secondary schools

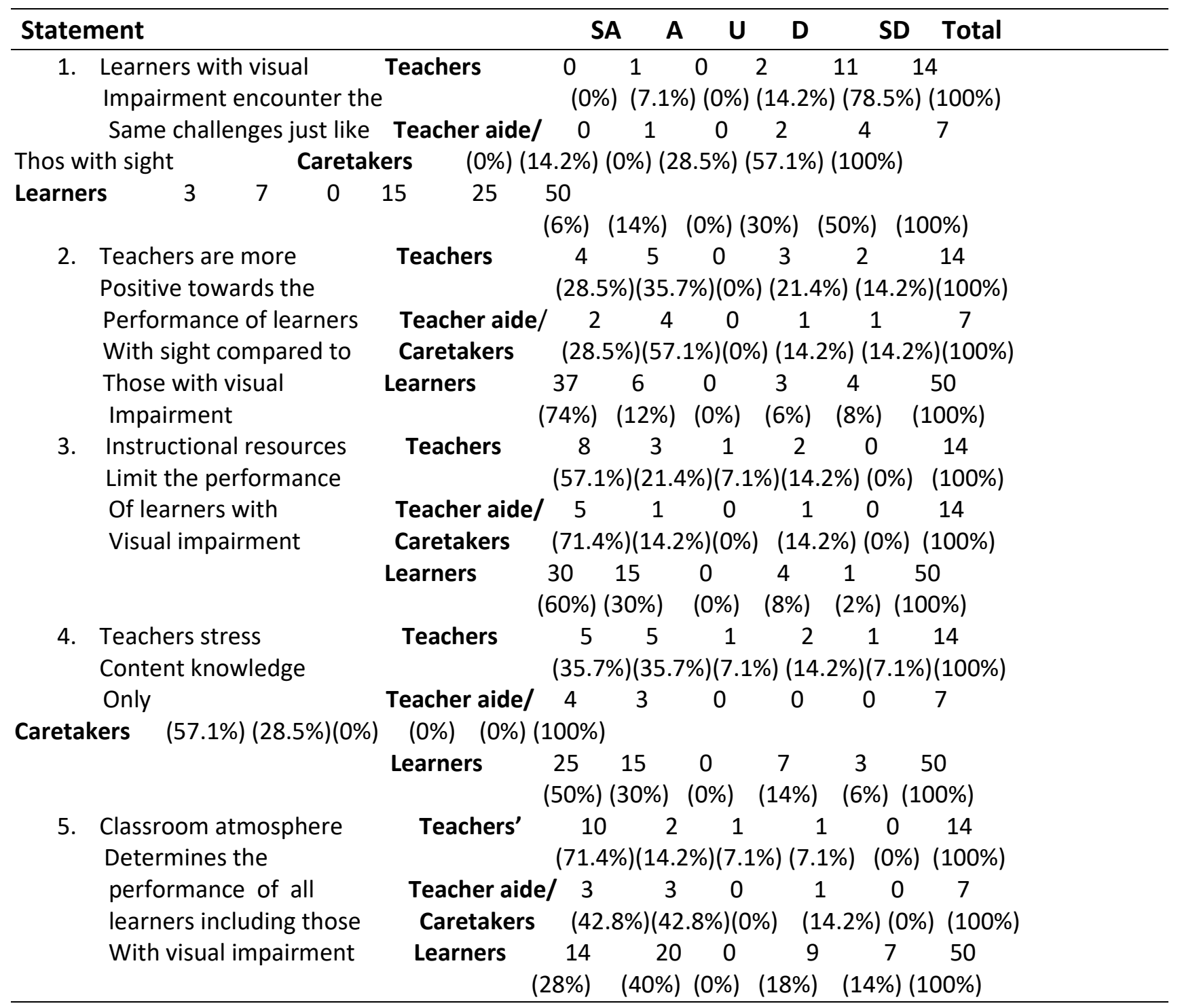


INTERNATIONAL JOURNAL OF ACADEMIC RESEARCH IN PUBLIC POLICY AND GOVERNANCE Vol. 7, No. 1, 2020, E-ISSN:2312-4040@ 2020 KWP

Results in table 6 shows that, 1(7.1\%) of the teachers were in agreement that learners with visual impairment encountered the same challenges just like those with sight.13(92.7\%) disagreed. $1(14.2 \%)$ of the caretakers agreed and $6(85.6 \%)$ disagreed. $10(20 \%)$ of the learners agreed and $40(80 \%)$ disagreed. $9(64.2 \%)$ of the teachers agreed that, teachers were more positive towards the performance of learners with sight compared to those with visual impairment, 5(35.6\%) disagreed. $6(85.6 \%)$ of the caretakers agreed and $1(14.2 \%)$ disagreed. $43(86 \%)$ of the learners were also in agreement and $7(14 \%)$ disagreed. $11(78.5 \%)$ of the teachers agreed that instructional resources limited the performance of learners with visual impairment, $2(14.2 \%)$ disagreed and $1(7.1 \%)$ was undecided. $6(85.6 \%)$ of the teacher aide and caretakers agreed and $1(14.2 \%)$ disagreed. $45(90 \%)$ of the learners agreed and 5(10\%) disagreed. 10(71.4\%) of the teachers agreed that teachers stressed content knowledge only. $3(21.3 \%)$ disagreed. $7(100 \%)$ of the teacher aide and caretakers agreed. $40(80 \%)$ of the learners agreed and $10(20 \%)$ disagreed. $12(85.6 \%)$ of the teachers agreed that classroom atmosphere determines the performance of all learners including those with visual impairment. 2(14.2\%) disagreed. $6(85.6 \%)$ of the teacher aide and caretakers agreed and $1(14.8 \%)$ disagreed. 34(68\%) of the learners agreed and 16(32\%) disagreed.

The data in table 6 shows that, both the teachers, teacher aide, caretakers and learners were in agreement that learners with visual impairment did not encounter the same challenges like those with sight. Learners with visual impairment became isolated from others more easily making it difficult for them to participate actively like the sighted learners. They explained that teachers were more positive towards the performance of learners with sight compared to those with Visual Impairment. Education as aright belonged to all children regardless whether they were normal or had disabilities and that the development of a child was in education as it impacted the whole life. Both the teachers, teacher aide, caretakers and learners explained that the instructional resources limited the performance of learners with visual impairment and teachers stressed content knowledge only. Poor academic performance among learners with Visual Impairment was linked to the use of teaching resources which were ineffective by teachers to impact knowledge to these learners (Adunola, 2011). They agreed that the classroom atmosphere determined the performance of all learners including those with visual impairment. This was supported by Jordan\& Kathy- Ann (2004) that modification of the classrooms was a requirement to meet the varied needs of learners and enhance their performance. Schiro (2012) in support of Dewey (1897) explains that, the nature of methods used during instructions is to focus on the power and interest of the child. The government of Kenya, since independence, has established educational commissions to deliberate on sustainability of the educational provision for all children with and without disability. Education For All (EFA)-Kenya (2001) advocated for education to be free and available to all Kenyans. Steps towards inclusive education included the Bill for children (2001) and the Bill for Disability (2002). Both bills recognized the educational rights of children living with disability and more so those who are Visually Impaired.

\section{Conclusion}

Learners with Visual Impairment encountered more challenges in integrated classrooms as compared to those with sight. These classrooms were overcrowded. The school environment was not modified to suit the needs of learners with Visual Impairment and there were insufficient instructional teaching resources in integrated secondary schools. The school community had misconception about learners with Visual Impairment considering them to be a burden. There was inadequate funding for programs which support learners with Visual Impairment. Teachers were more positive towards the 
INTERNATIONAL JOURNAL OF ACADEMIC RESEARCH IN PUBLIC POLICY AND GOVERNANCE Vol. 7, No. 1, 2020, E-ISSN:2312-4040@ 2020 KWP

performance of learners with sight than those with Visual Impairment. In integrated classrooms, teachers stressed content knowledge only.

\section{References}

Adunalo, O. (2011). The impact of teachers, Teaching Methods on the academic performance Ego Books, Ogun State, Nigeria.

Ayeni, A. J. (2011). Teachers Professional development and quality assurance in Nigeria Secondary Schools: World Journal of Education, 1(2) 143-149

Jordan, Kathy- Ann \& Ramaswamy, S. (2004). Global Perspectives on Inclusion. Global Education. Review, (1). 10-13

Kothari, C. R. (2009): Research Methodology: Methods and techniques(2 ${ }^{\text {nd }}$ Ed). New Delhi. Age International Publishers

Schiro, M. S. (2012). Curriculum theory: Conflicting Visions and enduring concerns. $\left(2^{\text {nd }}\right.$ Ed.) Los Angeles: Sage Publications

Solomon, M. W. (2009). Curriculum and General Teaching Strategies for Learners Impairments. Journal of Blindness Innovation and Research. 6(1). 